\title{
Os meios justificam os fins: gestão baseada em valores - da ética individual à ética empresarial. São Paulo: Pearson Prentice Hall, 2005, de Ricardo Vargas
}

\section{Raquel da Silva Pereira}

raquelsp@uninove.br, Uninove, São Paulo - SP [Brasil]
Escrever sobre ética exige, além de muito conhecimento, coragem. Aliar teoria e prática neste campo conturbado torna-se um desafio. A formação e o perfil profissional do psicólogo Ricardo Vargas, autor de Os meios justificam os fins: gestão baseada em valores - da ética individual à ética empresarial, consultor organizacional, pesquisador e conferencista, fazem com que ele tenha uma visão de gestão que integra conhecimentos multidisciplinares na utilização de metodologias inovadoras, para responder aos desafios da Administração. Para dar conta dessa temática, o autor aborda questões sobre valores individuais e universais, que tangenciam moral e cultura, com implicações também na legislação.

Em tempos de globalização, muitos hábitos e costumes se mesclam; no entanto, algumas culturas continuam intactas, mesmo neste início de terceiro milênio. Persistem valores sociais importantes para determinadas culturas, mas fortemente questionados por outras. Essa forma de desenvolvimento da economia internacionalizada influencia e questiona os valores das comunidades, que, por sua vez, decorrem do desenvolvimento histórico do contexto local. Comparar tais distinções é salutar, pois possibilita escolhas, que levam à liberdade. Só é livre quem escolhe e, para que se façam boas escolhas, é necessário conhecer diferentes realidades. Não há escolha se não houver opções. A quebra de paradigmas culturais pode ser difícil e dolorosa, em razão de o homem apresentar dificuldade para desaprender o que está estabelecido, enfim para dar lugar ao novo, apesar de ter consciência da riqueza e da importância desse processo reflexivo, que aponta sempre para novas perspectivas.

Por um lado, fortalecem-se princípios universais como a liberdade, a igualdade entre as pessoas e o valor da vida humana, mesmo que, para alguns, esses não sejam motivos de reflexão; por outro, o ser humano há muito se depara com juízos de valor, entre o bem e o mal, e é possível que continue a questionar-se sobre esses dois pólos.

Os valores pessoais, segundo Vargas, apesar de não serem escolhidos e dependerem da interação do indivíduo com o ambiente, determinam suas ações profissionais, balizadoras das tomadas de decisão dos gestores e, portanto, influenciam diretamente na vida das pessoas e das equipes por eles geridas.

Vargas transita, de maneira tranqüila, em seu livro, por todos esses conceitos. Por meio dessas concepções estabelece como a ética individual determina a ética profissional e, conseqüentemente, a da empresa, além de apresentar os benefícios dessa nova cultura. Ainda põe a ética como parte da responsabilidade social corporativa, analisa o comportamento humano, partindo do pensamento filosófico até alcançar a aplicabilidade da ética empresarial, demonstrando que essa abordagem é possível e vantajosa para as organizações.

O autor defende a idéia de que as empresas devem gerir a ética e, por meio dela, a cultura empresarial, sendo factível conduzir mudanças culturais com base nesse modelo de gestão. Propõe uma gestão baseada em valores, com transparência e critérios claros, numa relação de parceria entre empresa, empregados e sociedade, em que todos ganham. Nesse contexto, a obtenção de certificações torna-se secundária, pois todos participam do processo e acreditam nele. Propõe, como necessária, uma mudança da cultura estabelecida, em que todos querem levar vantagem, e na qual se defende a idéia de que os fins sempre 
justificam os meios. Essa mudança depende de um processo educativo que, como toda mudança cultural, é lento, apesar de importante.

Nessa perspectiva, ensinar ética aos futuros administradores é extremamente necessário e não menos importante que outros conteúdos, devendo o estudante, no exercício de suas competências e habilidades, nortear-se por princípios éticos. $O$ profissional de Administração, além de liderar equipes, tomará decisões que afetarão, positiva ou negativamente, as pessoas que trabalham na empresa, a comunidade local e, em sentido amplo, a global. Isso demonstra a importância de suas ações, denotando elevado grau de responsabilidade.

Sabendo-se que não há duas organizações com culturas idênticas, assim como uma impressão digital, é difícil reproduzir a cultura de uma organização. Gerir cuidadosamente essa cultura é uma estratégia competitiva de diferenciação que se inicia pela gestão de pessoas. As organizações são compostas de pessoas que, por sua vez, determinam a cultura da instituição.

Em síntese, a abrangência da obra, muito bem delineada em suas 202 páginas, estimula a reflexão sobre os valores contemporâneos individuais e organizacionais, alertando para a consciência das escolhas que fazemos.

No primeiro capítulo, o autor aborda "a força invisível”, esclarecendo que o gestor é responsável não só por suas ações, mas também pela influência que exerce nas decisões das outras pessoas no âmbito da empresa em que ele atua, mostrando a dificuldade em estabelecer o alcance dessas ações e suas conseqüências.

No segundo, define limites que diferenciam valores, ética e moral, apontando, entretanto, quanto estão inter-relacionadas.
No terceiro, questiona a moralidade de maneira inteligente, estabelecendo relações entre autoridade moral, poderes religioso e legislativo, que determinarão critérios sobre o que é certo ou errado para determinada comunidade. Ressalta que o que é certo para um povo pode não ser para outros, dependendo muito da lente através da qual olhamos as situações.

No quarto capítulo, aborda o estreito caminho da ética individual entre o bem e o mal, relacionando integridade com compromisso moral. Escreve ainda sobre os conflitos morais do ser humano.

No quinto, esclarece que todas as empresas são éticas, que a cultura de uma organização é algo complexo, formado por padrões que se estabelecem ao longo do tempo. O que ocorre é que, cada vez mais, os consumidores questionam determinados padrões éticos, o que justifica a preocupação das empresas com a temática.

No sexto, Vargas discorre sobre a gestão da ética empresarial, para a qual deve haver critérios, evitando desperdícios de energia das pessoas e, portanto, de produtividade. Deixa claras as vantagens da organização que explicita seus valores, descrevendo, inclusive, um modelo para a gestão de conflitos de valores, além de oferecer instrumentos para a gestão da ética.

O sétimo capítulo trata da gestão com base em valores, sugerindo a definição operacional para cada valor da organização, por meio de comunicação clara aos colaboradores. Assim, encerra inteligentemente seu livro, deixando, no último capítulo, uma provocação para a escolha e consciência individual que, como exposto, refletem na organização e na sociedade. 